\title{
Research on the Mode of University-Enterprise Cooperation to Promote Engineering Students' Employment
}

\author{
Yan Hui ${ }^{*}$, Sun Lihua ${ }^{2}$ \\ 1.Shandong Women's University, Teaching Affairs Office, Shandong, China \\ 2.Shandong Women's University, School of Data and Computer Science, Shandong, China
}

\begin{abstract}
The employment of university students has become a hot issue of concern to the whole society. Promoting the employment of university students is a top priority for higher education institutions. University-enterprise cooperation is an important trend in the development of modern higher education. It is also an important channel for promoting the employment of university students, especially for engineering students. Through an in-depth analysis of the status quo of employment of university graduates, this paper proposes four modes of university-enterprise cooperation to promote university graduates' employment: The post-employment cooperation model, the professional internship cooperation model, the second classroom expansion cooperation model and the enterprise-oriented recruitment model, and further proposed the countermeasures to strengthen the cooperation between university and enterprise in order to promote the employment of university students.
\end{abstract}

\section{Introduction}

After decades of development, higher education in China has achieved remarkable results. With the continuous development and growth of higher education, it has also brought about some problems. Although the number of university graduates in engineering universities has increased significantly in recent years, it is very scarce to be qualified for professional and technical personnel in the field of science and technology.

One outstanding problem is that professional qualities and technical skills of engineering university students cannot meet the needs of the job. For this reason, universities and universities are actively exploring and reforming the existing personnel training model, hoping to find ways and means to solve the problem, in which the university-enterprise cooperation model is increasingly recognized by universities and enterprises. University enterprise cooperation mode can achieve the goal of personnel training, enhance the vitality and strength of running universitys, and improve the level of running universitys and the quality of education. At the same time, it will help to meet the needs of social and economic development, provide high-quality resources for enterprises, and solve the problem of employment of engineering students in universities.

\section{Analysis of University Students' Employment Status}

The employment of university graduates is an important part of the employment of the whole society. The employment of university graduates is an essential requirement for improving the quality of higher education and maintaining the sustained and healthy development of higher education.

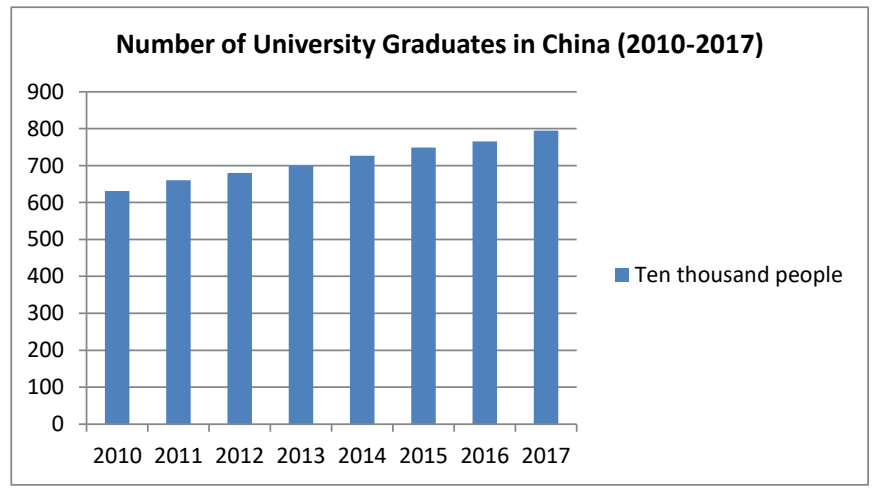

Fig. 1 Number of university graduates in China (2010-2017)

As showed above, the number of university graduates has increased year by year. With the continuous increase in the size of enrollment, the number of graduates entering the job market every year has increased year by year. It can thus be seen that the employment situation of university graduates has become increasingly severe. This is an inevitable result of China's higher education entering the popularization stage from the elite stage. At the same time, it also reflects the importance that Chinese families attach to higher education from another perspective.

\footnotetext{
* Corresponding author: yanhuibangong@126.com

(C) The Authors, published by EDP Sciences. This is an open access article distributed under the terms of the Creative Commons Attribution License 4.0 (http://creativecommons.org/licenses/by/4.0/).
} 


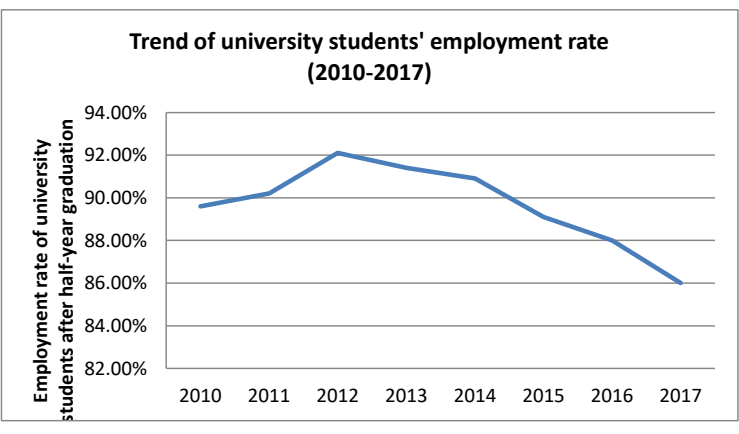

Fig. 2 Employment rate of university graduates in China (2010-2017)

It can thus be seen from Fig 2 that the employment situation of university graduates has become increasingly severe. This is an inevitable result of China's higher education entering the popularization stage from the elite stage. At the same time, it also reflects the importance that Chinese families attach to higher education from another perspective.

\section{Advantage of University Enterprise Cooperation in Promoting University Engineering Students' Employment}

Firstly, university-enterprise cooperation is conducive to the promotion of university curriculum development and promotes the integration of engineering students' learning and enterprise production. Secondly, university-enterprise cooperation is conducive to promoting the construction of university training bases. Students can participate in the actual work of the company during the study period, make up for the lack of professional knowledge, and strengthen practical operation skills, so as to enhance innovation and practical ability.

From the enterprise perspective, university-enterprise cooperation can enhance the recognition of the quality of personnel training. Under the university-enterprise cooperation model, companies combine their actual situation and school needs, to sign the talent development agreement. University develops or adjusts its own teaching plans and curriculum settings in conjunction with the agreement so that students can contact the company during their studies. Under the university-enterprise cooperation model, higher education is no longer limited to the theoretical teaching of the campus. Engineering students can integrate into the production team within a short period of time and continue to enhance their comprehensive professionalism. University-enterprise cooperation places great emphasis on the matching of school education with the current industry and enterprise skill requirements. Both the teaching arrangement and teaching evaluation incorporate the opinions of industry and enterprise experts, and timely make relevant adjustments in light of changes in the social and industrial human resources markets. This not only communicates the theoretical knowledge of the university and the company's production practices, but also promotes the transformation of the traditional talents from the traditional knowledge transfer to the improvement of the overall professional quality, which not only improves the quality of education, but also innovates the mechanism for employing.

\section{Influence of University Enterprise Cooperation on Promoting Engineering Students' Employment}

\author{
4.1 Improving the pertinence of engineering talent \\ training
}

The cooperative education model between universities and enterprises can further improve the function of higher education, optimize the educational model, and fully integrate the functions of education and training with the functions of the service enterprise, so as to give full play to its advantages in resources and meet the needs of enterprise development, school teaching and student personal growth. Therefore, colleges and universities should combine the actual needs of the human resources market with their own reality, optimize their own education plans, adjust curriculum settings, and strengthen links with current social needs so as to achieve the best results in running schools.

\subsection{Promoting all-round cooperation and establish stable employment channels}

There are often significant differences between the operating mechanism of enterprises and university teaching models, which results in limited participation of enterprises and inefficient cooperation. The main reason is that universities do not pay attention to the linkages and cooperation with enterprises, and there is no perfect long-term mechanism for university-enterprise cooperation. To achieve the institutionalization and standardization of university-enterprise cooperation, it is necessary to construct a series of management systems. First of all, universities must work together to formulate and implement the talent training model through university-industry enterprises. Secondly, it should build a practical training base through university-enterprise collaboration to truly realize the integration of universities and enterprises. Finally, it can build a teaching team and set up business scholarships to reward university engineering students who are highly qualified. Through all-round cooperation between universities and enterprises, a stable employment channel will eventually be established.

\section{University-Enterprise Cooperation Model}

\subsection{Zero distance training model}

Universities shall vigorously advance education and teaching reform according to market demand, adhere to the concept of zero distance training in teaching, internship, and graduation, and realize the integration and cooperation of university-enterprise education and teaching, practice training, and employment, and establish the zero distance training mode between university and enterprise. By integrating high-quality resources such as teaching, research, and base, universities and enterprises will establish a perfect practice teaching system to achieve seamless connection between 
university and enterprise cooperation.

\subsection{Building a dual-qualified teacher team}

Under the conditions of university-enterprise cooperation, colleges and universities need to establish a team of dual-qualified teachers who understand both theory and practice. Colleges and universities should send teachers with rich professional teaching experience and solid foundation teaching to go deep into enterprises to participate in production practices or joint scientific and technological research to improve teachers' practical ability and technological innovation ability to meet the needs of practical teaching. At the same time, companies should select practical and technically experienced business and technical backbones to participate in the practice of teaching activities in colleges and universities, and specifically guide students to practice training. Through the establishment of a two-way exchange mechanism for university-enterprise talents, a "dual-qualified" faculty team is created.

\subsection{Pursuing the integration of "theory and practice" teaching}

Colleges and universities should effectively change the teaching concept, abandon the traditional theoretical teaching model, and gradually establish the theory plus practice integrated teaching model. In the professional training program, it is necessary to make adjustments and revisions in accordance with market demand; in terms of curriculum setting, and to pay attention to the ratio of professional basic courses, practical courses, and public basic courses, to highlight practicality and application. In terms of teaching methods and means, it is necessary to constantly carry out innovative reforms in accordance with the characteristics of the curriculum, and to improve the effectiveness of practical teaching.

\subsection{Cooperating to establish an innovation base for production, education and research}

The innovation base of production, education and research established by cooperation between universities and enterprises is an important place for implementing quality education to cultivate students' innovative ability and practical ability. It is also a direct platform for cultivating students' innovative ability, and provides a transition and preparation for students' employment.

\section{Conclusion}

Under the background of difficult employment for university students, the university-enterprise cooperation model enables students to understand the company's needs for talents in the school. This is a university-running road worthy of continuing research and exploration. Through the two different learning environments, different knowledge and skills are acquired, and comprehensive applied talents with innovative spirit and abilities are developed to satisfy the needs of society and enterprises for professional and technical personnel, and the employment competitiveness and career development potential of undergraduates are improved.

\section{References}

1. Ministry of Education of the People's Republic of China Higher Education Department National Higher Vocational School Principals Association. Click Core-Higher Vocational Education Professional Setup and Curriculum Development Guide [M]. Beijing: Higher Education Press, 2017 : 130.

2. Wu Hongyu, Yang Qunxiang. Study on the factors affecting enterprises' cooperation between schools and enterprises-Based on the analysis of 910 questionnaire surveys $[\mathrm{J}]$. Vocational and Technical Education, 2012 (16): 15-20.

3. Chen Shenhan, Li Ke. Integrated teaching is a new educational revolution $[\mathrm{J}]$. Abroad and Employment, 2009, (10): 89.

4. Wang Yani. Misunderstandings and roles of school-enterprise cooperation [J ]. Vocational and Technical Education, 2007, (7): 40. 